\title{
The plastic surgeon Johannes Fredericus Samuel Esser (1877 to 1946), M.D., D.M.D. and his unknown period during 1917 and 1925 in Berlin, Germany
}

\author{
Jan M. Hilbert • Johannes F. Hoenig
}

Received: 8 September 2008 / Accepted: 15 December 2008 / Published online: 19 February 2009

(C) The Author(s) 2009. This article is published with open access at Springerlink.com

Keywords Johannes F. Esser · Plastic surgery · Berlin period

\section{Introduction}

Esser, who was known as a plastic surgeon, an art dealer, a ship's physician, a merchant and a champion chess player from Leiden in the Netherlands, practised all over Europe before he became a resident of Berlin. During this time and the First World War, he published articles about his work in the field of plastic and reconstructive surgery in distinguished international journals. The techniques Esser developed for reconstructing facial defects are well known to plastic surgeons [1-8]. So Esser attracted the attention of three university professors in Berlin. Because of these innovative techniques, they offered him a position in 1917 as head physician for plastic surgery. Yet, Berlin medical history today does not sufficiently credit Esser for his achievements in disseminating the knowledge of plastic

J. M. Hilbert $(\bowtie)$

Department of Maxillofacial and plastic facial Surgery,

Military-Hospital of Ulm,

Oberer Eselsberg 40,

89081 Ulm, Germany

e-mail: JanHilbert@gmx.de

\section{J. F. Hoenig}

Georg-August-University Hospital

and Medical School of Goettingen,

Robert-Koch-Street 40,

37075 Goettingen, Germany

\section{J. F. Hoenig}

Plastic Surgery Center, Paracelsus-Clinic,

Oertzeway 24

30851 Hannover/Langenhagen, Germany

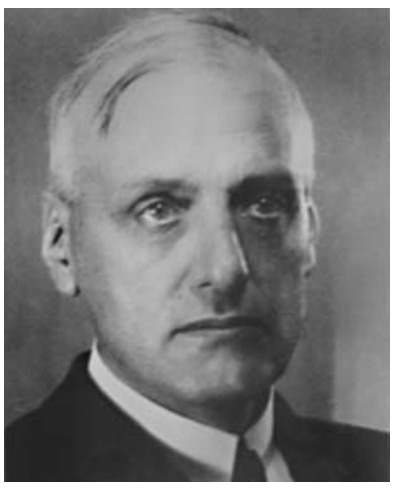

surgery, as both the physician and his work were forgotten in Berlin after the Second World War. Analysis of hitherto unreferenced documents demonstrates that Esser was leading the field of plastic surgery, which at the time was not recognised as an independent area of surgery. His work during the Berlin period from 1917 to 1925 convinced international experts of the potential of this profession, its importance for the field of surgery and its significance for each disfigured patient. These documents supplement statements published by Haeseker in 1983 [9] and Neelissen in 2002 [10]. Esser enjoyed even better conditions in Berlin than in Budapest where he had worked previously. Berlin was the most important centre for surgery from the early nineteenth century on [9]. In addition to his work as a physician, Esser [11] was also an uncompromising businessman, an enthusiastic art collector and a passionate chess player.

\section{Esser the physician}

Esser's curative work in Germany began with his acquisition of a German medical license. He had finished his 
medical studies with the final exam in 1903 [10] in Leiden, The Netherlands and not at one of the Prussian universities as was usually prerequisite for receiving a medical license. In November 1918, Esser was awarded a medical license by the Ministry of the Interior or, more precisely, the Ministry of Science, Art and National Education. This was just 1 year after he began his work on Oct. 1, 1917 in Berlin and was based on his outstanding achievements in the area of plastic surgery. Bier, a famous general surgeon and Chief of the Department at Friedrich Wilhelm University Hospital, known today as Humboldt University Hospital, recommended him emphatically. Such honors had, up to that point, only been bestowed on three other persons [12].

As early as April 10, 1918-before acquiring his medical license-Esser was appointed "specialist for plastic surgery" by the Prussian Ministry of War [10].

He worked at university clinics in the departments of surgery (headed by Bier), ophthalmology (Krückmann) and prosthodontics (Schröder). Esser was not employed as a resident in Bier's clinic. His status was comparable to that of the head of an independent department. This led to resentment on the part of Bier's residents, particularly Wilhelm Baetzner [12], but this was unintentional on Esser's part. On the contrary, Esser tried to smooth it over [12].

In department IIIb for "structive surgery" at the Technical University of Berlin, Germany in the Charlottenburg district, which had been converted to a battlefield hospital, Esser had charge over another 150 beds [13, 14]. In addition, he worked in private practice in Berlin's Tempelhof district and as a consultant at 19 other Berlin hospitals and practices. Esser operated on request as a consultant for Berlin's bestknown surgeons, with special focus on plastic reconstructive surgery of the face.

\section{Special operations}

These include the treatment of frostbite [15], the improvement of pre-prosthetic-kineplastic amputation-stump formation [16, 17], various arterial lobes [18] and cheek rotation flaps to cover facial defects. Esser also performed facelifts and breast reconstruction as well as hand and foot operations, including transplantation of toes.

\section{Publications}

Most notable are 68 multilingual articles published within 8 years in specialist journals, the monograph "The Cheek Rotation and General Comments on Plastic Surgery of the Face" in 1918 (see [14]) as well as "Artery Flaps" (1929) which was written in Berlin but published later. The "Esser Inlay" was first published as a compendium in 1940. The findings of this monograph had already been made available in various individual articles.

\section{Assistants}

Esser trained only a few assistants. Almost all of them came from other European countries and immigrated in the early 1920 s to the USA. Esser's training was fundamentally different from training offered by Jacques Joseph (1865-1934) and Hugo Ganzer (1979-1960) who also worked in the field of reconstruction of facial defects. If Esser was convinced that an assistant was competent, that assistant received specific practical training in addition to observing operations. Among his most well-known assistants were Gustave Aufricht (1894-1980) [19-21], Jacques W. Maliniac (1889-1976), who founded the ASPRS in 1931, and Joseph Safian (1886-1983) [22].

The list of physicians who profited from Esser's knowledge, whether through assisting him or [23] receiving his help as a consultant, was long. These were not counted among his "assistants". Esser was also constantly bombarded with requests for collaboration. He was never able to establish a "school" of his own that could have continued his work.

\section{Advanced training for physicians}

On request of the Central Committee for Advanced Training for Physicians, Esser designed an eight-part lecture series on the different areas of plastic surgery [24-30]. Even back then, the lectures were made up of a theoretical and a practical part. They began on Wednesday, January 10, 1922 at 6:45 P.M. The theoretical part was held at the Kaiserin Friedrich House, located in the centre of Berlin at Luisenplatz (now called Robert Koch Plaza), the top location at the time for advanced training for physicians.

\section{Specialist societies}

There were three scientific forums of particular note: the Berlin Medical Society (Berlin Medizinische GesellschaftBMG), the Berlin Oto-Laryngological Society and the War Physician Dinners. The discussions were heated. In particular, J. Joseph repeatedly criticised Esser [31, 32]. In Esser's memoirs, which were never completed or published, he mentions that J. Joseph heard about Esser's operating methods from the dentist Brill. At a later case presentation, however, J. Joseph failed to mention that he used Esser's surgical techniques and developments [12]. Other participants, such as ear, nose and throat specialist Max Halle (1873-1939), sided with Esser [33]. 
Esser himself received lively applause for his contribution to war (surgery) at the 12th meeting of the Berlin Medical Society (BMG) on May 10, 1922.

\section{The missed professorship}

Esser never received the professorship of plastic surgery which was offered to him at the end of 1919. Despite extensive correspondence between Esser and Krückmann from November 1919 to November 1921 [34-37], Esser's application was never granted and Esser left Berlin in 1925 without ever acquiring this title.

\section{Esser the merchant}

Esser founded several companies [38] to manage his real estate in Berlin and abroad. In Berlin alone, he owned more than 200 items of property [38].

An article in the Berlin Steglitz Anzeiger from March 13, 1926 reports that tenants of Esser's properties were enraged at the sums they had to pay in compensation when they cancelled a lease.

Furthermore, the tax authorities made additional claims on Esser on the basis of false declaration of his assets [for 1924 , the difference amounted to $11,887,700$ reichsmarks (today about US $\$ 53,280,671.40]$. He also was fined by the Berlin district attorney for 1,200,006.60 reichsmarks (today about US $\$ 5,378,429.60$ ).

A warrant for Esser was issued [38] and a penalty set [39], but the action was dismissed on April 27, 1927, considered groundless [40] and thus cancelled [41].

\section{The art dealer}

Dealing in art made Esser a wealthy man and made him solvent to deal in different branches, e.g. real estate. In the field of modern art collection, Esser had also been one of the pioneers. He mainly amassed paintings of the early Dutch modernist art called "Amsterdam Luminist art". In the end, there was a collection of more than 800 paintings. The list of artists shows many names (e.g. painters) such as Jan Sluijters, Leo Gestel, Piet Mondrian and Piet van der Hem. In many cases, Esser supported them in different ways [42].

\section{After Berlin}

Subsequent to the Berlin period, Esser's main interest was to establish an independent state of plastic and reconstructive surgery where all wounded and deformed could be treated regardless of their financial situation or citizenship.

\section{Conclusions}

Johannes Fredericus Samuel Esser, Dutch physician and man of many talents, was one of the most influential and outstanding plastic surgeons of the early twentieth century. It was through his efforts that this specialty area was acknowledged scientifically and became well known to experts in the field. His Berlin years, from 1917 to 1925, saw his greatest contribution to the proliferation and establishment of plastic surgery, thanks to his assistants, his innovative surgical techniques, the 23 hospitals in which he operated, his publishing activities and discourse with colleagues at meetings of specialist societies. Berlin's international reputation in the field of surgery and the infrastructure available at that time supported Esser's goals. Just as his interests varied widely, so too did his actions as a humane physician on the one hand differ from his role as a hardened businessman on the other.

Esser must not be forgotten when commemorating outstanding Berlin surgeons, particularly those who were active at the Friedrich Wilhelm University clinics (Ziegelstrasse 5/9): Carl F. Graefe (1787-1840), Johann F. Dieffenbach (1792-1847), Bernhard v. Langenbeck (1810-1887), Ernst v. Bergmann (1836-1907), Erich Lexer (18671937), Karl August Gustav Bier (1861-1949) and Fritz König (1866-1952).

Open Access This article is distributed under the terms of the Creative Commons Attribution Noncommercial License which permits any noncommercial use, distribution, and reproduction in any medium, provided the original author(s) and source are credited.

\section{References}

1. Manninger W (1942) Kampf und Sieg der Chirurgie. Rascher und Cie.A.-G.Verlag, Zürich, p 245

2. Yunchuan P et al (2006) Use of the lateral intercostal perforatorbased pedicled abdominal flap for upper-limb wounds fromm severe electrical injury. Ann Plast Surg 2:116

3. Depoorter M (2005) JFS Esser. In: Viering 50-jarig Bestaan van de Belgische Vereniging voor Plastische, Reconstructive en Esthetische Chirurgie.Vrijdag 6 mei-Zaterdag 7 mei, Brussel, p 43

4. Hoffmann-Axthelm W (1995) Die Geschichte der Mund-, Kieferund Gesichtschirurgie. Quintessenz Verlags-GmbH, Berlin, p 252

5. Jackson IT (2004) Midline forehead flaps in nasal reconstruction. Eur J Plast Surg 27:105

6. El-Khatib HA (2003) Bilobed fasciocutaneous flap for reconstruction of the posterior neck after necrotizing fasciitis. Plast Reconstr Surg 4:885 
7. Copcu E et al (2003) The study of expanded tri-lobed flap in a rabbit model:possible flap model in ear reconstruction. BMC Surg 3:13

8. Kostianovsky AS, Sostaric NM (1992) cornerstones in reconstructive plastic surgery: Argentinian development of muscular, myocutaneous, and fasciocutaneous flaps. Aesthet Plast Surg 16:34

9. Haeseker B (1983) Dr. JFS Esser and his influence on the development of plastic and reconstructive surgery. Med. dissertation, Rotterdam, p 60

10. Neelissen AJM (T) (2002) Het tomeloze Leven van Johannes EsserGrondlegger van de plastische Chirurgie, 1st edn. Uitgeverij Balanas, Amsterdam, p 30, 105

11. Esser JFS, Bardelli L, Coelst M, Gillies H, Kilner P, Eastman SJ (1940) Esser Inlay, 1st edn. E.J. Brill, Leiden (cover)

12. Esser JFS (1941) Autobiography. Rijksbureau voor Kunsthistorische Documentatie (RKD). The Hague, p 352, 348-349, 342343

13. Esser JFS (1920) Letter from Dr. Esser to Dr. Mikley, Berlin, Germany. Family Archive of J F S Esser, Rijswijk, The Netherlands, pp 1-2

14. Esser JFS (1918) Die Rotation der Wange und allgemeine Bemerkungen bei chirurgischer Gesichtsplastik, 1st edn. F.C.W. Vogel Verlag, Leipzig

15. Esser JFS (1917) Gestielte Plastiken bei typischen Erfrierungen und bei schlecht verheilten Amputationsstümpfen der unteren Extremität. Bruns'Beitr Klin Chir 108:515

16. Esser JFS (1919) Plastische Deckung von Defekten durch sogenannte "Einnähung". Dtsch Z Chir 148:385, 385

17. Esser JFS (1919) Deckung von Amputationsstümpfen des Oberschenkels aus dem Arm bei beiderseitig Amputierten durch "Einnähung". Zentralbl Chir 46:22-25

18. Esser JFS (2003) Artery flaps. Facsimile: Johannes Fredericus Samuel Esser-artery flaps. Introduced by Prof. Dr. J.C. van der Meulen. Facsimile Erasmus Publishing I, Rotterdam, pp 15-143

19. Natvig P (1982) Jacques Joseph-surgical sculptor. Saunders, Philadelphia, pp 51-52

20. Haeseker B (1986) Johannes Fredericus Samuel Esser: innovative "structive" surgeon (1877-1946). Plast Reconstr Surg 77:146

21. Aufricht G (1933) Letter from Dr. Gustave Aufricht, M.D., 103 East 66th Street, New York, NY, United States of America, to JFS Esser, Villa de Millo, Rue de Millo 33, Monaco, Frankreich. March 16th

22. Hait P, Schnur P (2005) The history of plastic surgery, ASPS and PSEF - the early years. Available via DIAOLG. http://www. plasticsurgery.org/History.cfm. Accessed 24 June 2005

23. Esser JFS (1922) Ueber struktive Chirurgie. Muench Med Wochenschr 69:502

24. Esser JFS (1922) Ueber Arterienlappen, Epitheleinlagen, verschließbaren Anus praeter naturalis und Reserveknorpel in der struktiven Chirurgie. Med Klin 18:793

25. Esser JFS (1922) Die Rotation der Wange. Muenchner Med Wochenschr 69:780
26. Esser JFS (1922) Schnittführungen in der struktiven Chirurgie. Muench Med Wochenschr 69:818

27. Esser JFS (1922) Hautbeschaffung aus Mamma und Präputium u. s.w. Muench Med Wochenschr 69:888

28. Esser JFS (1921) Unterbau in der struktiven Chirurgie. Muench Med Wochenschr 69:966

29. Esser JFS (1922) Metalleinlagen und Schusterspanverbände. Muench Med Wochenschr 69:1154

30. Esser JFS (1922) Verwendung von Geweben für verschiedene Zwecke. Muench Med Wochenschr 69:1186

31. Israel J (1918) Verhandlungen ärztlicher Gesellschaften-Vereinigte ärztliche Gesellschaften-Berliner medizinische Gesellschaft, Sitzung vom 12.Juni 1918. Berl Klin Wochenschr 27:650

32. Beyer J (1918) Verhandlungen ärztlicher Gesellschaften-Berliner Otologische Gesellschaft-Sitzung vom 22.März 1918. Berl Klin Wochenschr 38:914

33. Anonymus (1920) Verhandlungen ärztlicher Gesellschaften-Berliner Otologische Gesellschaft-(offizielles Protokoll), Sitzung vom 19. Dezember 1920. Berl Klin Wochenschr 12:282

34. Esser JFS (1919) Letter from Dr J F S Esser, Hardenbergstreet 40, Charlottenburg, Berlin, Germany to Prof. Dr. Emil Krückmann, Berlin. Germany. November 26th. Family Archive of JFS Esser, Rijswijk, The Netherlands

35. Esser JFS (1921) Letter from Dr J F S Esser, Hardenbergstreet 40, Charlottenburg, Berlin, Germany to Prof. Dr. Emil Krückmann, Berlin. Germany. November 5th. Family Archive of JFS Esser, Rijswijk, The Netherlands

36. Krückmann E (1921) Letter from Prof. Dr. Emil Krückmann to Dr. J.F.Esser, Berlin, Germany. November 17th. Family Archive of JFS Esser, Rijswijk, The Netherlands

37. Esser JFS (1921) Letter from Dr J F S Esser, Hardenbergstreet 40, Charlottenburg, Berlin, Germany to Prof. Dr. Emil Krückmann, Berlin. Germany. November 21st. Family Archive of JFS Esser, Rijswijk, The Netherlands

38. Landesarchiv Berlin (LAB), Berlin, Germany.LAB Rep.358-01 MFNr.A 654, Akte 885,Bl 2-5; Akte 884, Bl 3, 3.1; Akte 885, Bl 8-13, 15-19, 21-23, 25-30, 33-37, 39, 42, 44 -48, 50, 51, 53, 55, 57, 59, 61$65,67-69,71-75,77-78,80,81,85,87-92,94,96-99,101,103-106$, $108,110,112-113,115,117,118,120,123,128,140,140.1$

39. Landesarchiv Berlin (LAB), Berlin, Germany. LAB Rep. 358-01 MF-Nr.A 654, Akte 884, B1 3

40. Landesarchiv Berlin (LAB), Berlin, Germany. LAB Rep. 358-01 MF-Nr.A 654, Akte 884, B1.44

41. Landesarchiv Berlin (LAB), Berlin, Germany. LAB Rep. 358-01 MF-Nr.A 654, Akte 884, Bl.48

42. Anonymus (2007) CODART list-Museums with Dutch art \& Flemish art: Mondriaan, Breitner, Sluijters e.a.: de onstuitbare verzamelaar J.F.S. Esser (Mondriaan, Breitner, Sluijters, et al.: the irrepressible collector J.F.S. Esser) Available via DIALOG: http:// www.codart.n1/?page_id=119\&event_id=1013. Accessed 22 August 2007 